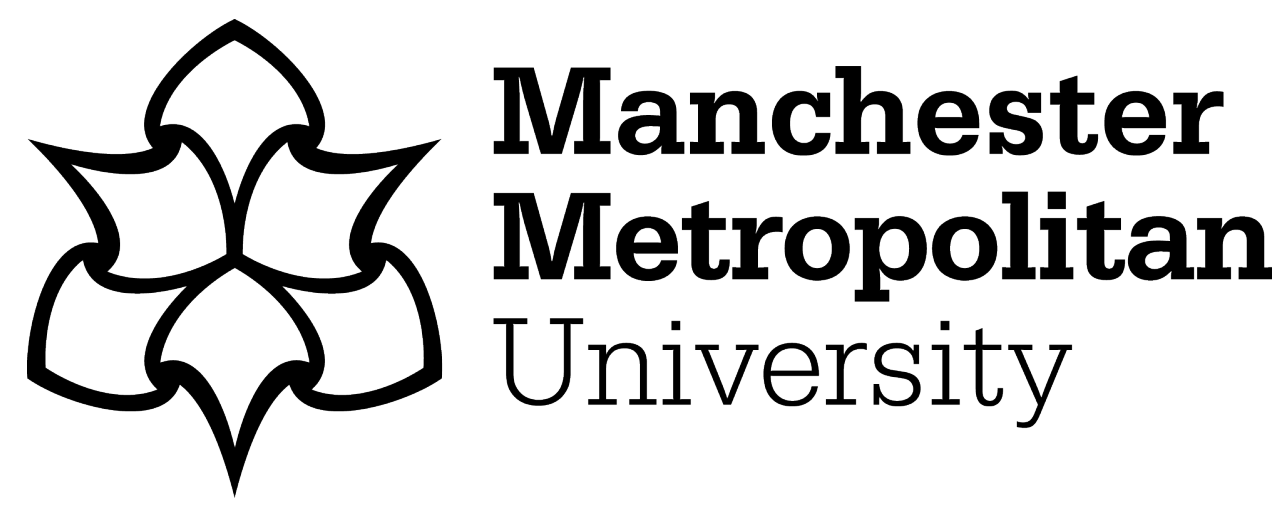

Rowley, Jennifer ORCID logoORCID: https://orcid.org/0000-0003-3437-6914 and Sircar, Atish (2020) How are UK churches using social media to engage with their congregations? Journal of Public Affairs, 20 (1). e2029. ISSN 1472-3891

Downloaded from: https://e-space.mmu.ac.uk/623784/

Version: Accepted Version

Publisher: Wiley

DOI: https://doi.org/10.1002/pa.2029

Please cite the published version 


\title{
How are UK churches using social media to engage with their congregations?
}

\begin{abstract}
Churches are important non-profit organisations that are increasingly adopting social media. In order to contribute to understanding of the value of social media as a communications channel for non-profit organisations, this article examines, and develops a typology of, the uses of social media by two global churches with a strong presence in the UK, Hillsong, a megachurch, and the Church of England. Informed by previous typologies of the use of social media in both commercial and non-profit contexts, content analysis was conducted of Hillsong's and the Church of England's social media platforms on Facebook, Twitter, Instagram and YouTube. This analysis provided the basis for the formulation of a typology of uses, the main categories of which are: building a brand, building the church community, outreach, and developing spiritual mission. Differences between the approaches adopted by the Church of England and Hillsong are outlined. Suggestions are offered for future practice and further research.
\end{abstract}

\section{Research paper}

Keywords: Churches; Non-profit organisations; Social media; Online communities; Facebook; Twitter.

\section{Introduction}

The purpose of this study is to explore the ways in which churches in the UK are using social media (SM) to communicate with their congregations, and to propose a typology of the uses of social media. From an academic perspective, the research contributes to the limited, but developing body of research on social media strategies, and responds to the evidence which suggests that many non-profit organisations are failing to exploit SM's potential for marketing, online engagement and relationship building (Bortree \& Seltzer, 2009; Rybalko and Seltzer, 2010; Wang and Yang, 2017). The existing literature also confirms that using multiple social media channels can have a mix of non-financial and financial benefits for organisations (Morgan, 2016). More specifically, social media allows organisations to gain social capital, engagement, visibility and communication (Gupta,et al., 2013) and can be an inexpensive and time saving solution for fundraising opportunities for non-profit organisations (Saxton, 2013). Social media has emerged as an important medium for both one-way and two-way 
communication with customers (Bacile, Ye and Swilley, 2014; Wade, 2015). Social media can also be used to build and protect corporate or brand reputation (Lee and Youn, 2009), and to increase customer engagement (Gummerus et al., 2012) and online sales (Chen, Fay and Wang, 2011). However, most research into social media use focusses on consumer engagement, satisfaction, or relationships (Kim and Ko, 2012; Okazaki et al, 2015; Trainor et al., 2014), leading to a paucity of studies on social media strategy, both generally, and more specifically in the context of non-profit organisations.

Given their focus on community building, and the potential for social media to change the nature of religious communication, communities and authority (Cheong, 2014, 2017), churches offer an interesting context in which to explore the use of social media. However, few studies have explored social media in churches (e.g. Cheong, 2014; Farquhar \& Davidson, 2019), and none have developed a typology of uses. This study builds on the limited research on the use of social media in the non-profit sector, some of which has proposed social media use typologies (e.g. DePaula et al., 2018; Guo and Saxton, 2014; Lovejoy and Saxton, 2012; Schlagwein and $\mathrm{Hu}, 2017)$.

The aim of this research is to understand how churches are using social media as a marketing and communications channel. The specific objectives are to:

- Profile the extent and nature of the social media of the churches' social media presence.

- Propose a typology of uses of social media, specifically tailored to churches.

- Offer suggestions for developing social media practice in churches and for further research into the use of social media by non-profit organisations.

Next, a review of previous research is presented. This is followed by an outline of the content analysis-based research methodology. The findings section first reviews the social media landscape for the two churches, and then proposes a social media use typology for churches. The article closes with discussion, conclusions and suggestions for practice and future research.

\section{Literature Review}

\subsection{Previous Research on Non-profit Organisations and Social Media}

There is a developing body of research that looks at the use of social media by non-profit organisations. Nah and Saxton (2012), Lovejoy and Saxton (2012), Saxton and Waters (2014) 
and Cho et al (2014) conduct content analyses relating to the social media presences of the 100 largest US non-profit organisations, whilst Lovejoy, Waters and Saxton (2012) study social media in US advocacy organisations, and Lovejoy, Waters and Saxton (2012) examine the use of social media to engage the stakeholders of 73 non-profit organisations. Bortree and Saltzer (2009), and De Paula et al. (2018) study US environmental advocacy groups, and local government social media, respectively. Finally, Ellison and Hardey (2014) undertake a content analysis of the social media presence of all English local authorities.

In terms of social media platform, there is a predominance of studies into Twitter (Guo and Saxton, 2014; Lovejoy and Saxton, 2012; Lovejoy, Waters and Saxton, 2012; Waters and Jamal, 2011) or Twitter and other platforms (Ellison and Hardey, 2014; Nah and Saxton, 2012;), with a very limited number of studies on Facebook (Bortree and Saltzer, 2009; De Paula et al., 2018). This may be because Twitter is the most widely used platform due to its immediacy for information provision (Ellison and Hardey, 2014). On the other hand, those studies that have examined Facebook and other social media sites provided greater evidence of the use two-way communication (dialogic communication) (e.g. Bortree and Seltzer, 2009; Cho et al., 2014). Finally, Saxton and Walton (2014)'s findings suggest that whilst individuals prefer dialogic communication, as well as certain forms of mobilisational messages, they are more likely to share one-way informational messages with their own networks. This suggests that there is scope for both informational and dialogic messages in a non-profit organisation's social media presences.

\subsection{Previous Research on Typologies of Social Media Use in Non-profit Organisations}

A number of the studies on the use of social media in non-profit organisation have developed social media use typologies. Earlier work on social media use typologies, including that by Auger (2013), Guo and Saxton (2014) and Lovejoy and Saxton (2012), identifies three main categories of uses of social media in non-profit and advocacy organisations, viz, information, community, and action. The uses identified within these three categories in these three models are also similar, but not totally aligned. Later researchers (e.g. De Paula et al., 2018; Gillooly et al., 2017) also feature information provision as a significant aspect of their typology, but are more explicit about nature of the 'informing' or 'information provision'. However, they also introduce other dimensions, such as entertaining, rewarding, and interacting (Gillooly et al., 2017), and input seeking, online dialogue offline interaction and symbolic presentation 
(DePaula et al., 2018). In addition, based in the for-profit sector, and focussing on the relationship between social media use types and organisations' absorptive capacity, Schlagwein \& Hu (2016) generate a very different social media use typology, on the basis of interviews with key informants in twenty organisations; this includes the uses: broadcast, dialogue, collaboration, knowledge management, and sociability. Taken together, this prior research suggests, perhaps not surprisingly, that the uses of social media are dependent on the organisation, and the wider context. Other research also suggests that the uses are likely to depend on social media channel. Specifically, Auger (2013) found that organisations were using the different social media channels for different purposes, typically providing thanks and recognition on Twitter, and soliciting feedback and two-way communication on Facebook. To some extent, these different uses are related to the functionalities of the different sites. For example, Kietzmann et al. (2011) suggest that the highest functionality of LinkedIn is associated with 'identity', for YouTube this is 'sharing', and for Facebook it is 'relationships'. On the other hand, there is a lack of consensus on the use and role of informational and dialogic (two-way) communication. For example, Lovejoy and Saxton (2012) are of the view that Twittter can be used for dialogic (two-way) communication, whilst Gillooly et al., (2017) found that the majority of sports sponsor tweets were of the informational type.

\subsection{Previous Research on Churches}

According to Cheong (2017), "we are witnessing the growth of a distinct sub-field focusing on new media and religion, as the relationship between the two is...vital'(p.25). However, the majority of the studies do not specifically focus on social media, but take a broader perspective on online churches and digital ministry (e.g. Campbell, 2012; Cheong, 2017; Hutchings, 2011; Rupp \& Smith, 2002). Central to these studies are: the impact on communicative practices, and spiritual authority within the church (Campbell, 2012; Cheong, 2017); and, the relationship between religion online and offline (Campbell, 2012; Hutchings, 2011). Research on social media is limited and tends to focus broadly on the role of social media in religious communities (e.g. Farquhar and Davidson), or on religious authority (e.g. Cheong, 2014).

Megachurches offer a particularly interesting context for this research for two reasons, their growth, and their engagement with a digital ministry. There are a number of previous studies on megachurches. For example, Martin et al. (2011) and Karnes et al. (2007) investigated the factors that influenced their growth, whilst Kim (2007) investigated their use of websites. More 
specifically, Hackett (2009) found that church leaders in three megachurches in Africa used websites to bolster their image, and to legitimise their authority. Sturgill's (2004) research on UK-based megachurches is the only study to examine megachurch websites from the perspective of marketing and branding. In addition to studies on megachurches, in general, there are a few studies that focus specifically on Hillsong. Whilst these mainly focus on religious practice (McIntyre, 2007; Klaver, 2015), Connell (2005) explains how the church has changed religious practices through creating social capital using modern technology and Eagle (2015) offers some analysis of Hillsong's use of the Internet. In summary, whilst there is some research into the megachurch model, there has been limited previous research into their use of the Internet and none on the way in which they use social media.

The Church of England has a considerably longer history than megachurches, and hence has attracted a number of research investigations, but as with megachurches, the research has a marginal relevance to the church's use of the web or social media. For example, earlier studies have explored the Church's accounting systems (Laughlin, 1988) investment practices (Kreander, McPhail and Molyneaux, 2004) and women's contribution and experiences (Levitt, 2003; Sani and Reicher, 2000). Adopting a more explicitly marketing and communications perspective, Muskett (2015) examined how the physical presence of Anglican cathedrals as the, 'shop windows of the Church of England' help towards making the church more visible. Arguably, relevant to this study is the recent work by Zigan and Le Grys (2018) on church members' views on social responsibility and engagement in the local community, an arena in which social media could potentially make a contribution.

\section{Research Methodology}

\subsection{Case study approach}

In order to investigate social media use by churches, this study adopts a comparative two-case study approach. A case study approach is adopted because case studies support in-depth and 'in context' analysis of a phenomenon. Case studies can be used to profile a situation and to develop insights. In addition, according to Eisenhardt (1989), case study research is useful for new research areas. As identified above, there is limited prior research on the use of social media by non-profit organisations and none on its use in churches. Furthermore, according to Rowley (2002), case studies are suitable for generating answers to 'how' questions; in this study the aim is to understand how churches use social media. Adopting a two-case approach 
is appropriate for an exploratory study and enhances the robustness and potential transferability of the findings to other contexts, and supports analysis and preliminary insights into the extent to which the phenomenon is context dependent.

One of the most important decisions in case study research is the choice of the case study units of analysis (Bryman and Bell, 2011). Two churches, Hillsong and the Church of England, were chosen for this study. They were selected because, as outlined previously, they are both large churches, with significant congregations scattered across numerous locations in the UK. In addition, they both make use of social media to communicate with their congregations. On the other hand, they have different histories, styles of worship, organisational structures, and demographics; it will be interesting to explore whether these factors impact on the types of use that they make of social media.

\subsection{Research context}

Hillsong was founded in Australia in 1983. It is one of the most successful megachurches, with locations in London, Kiev, Cape Town, Paris, Stockholm, Moscow and New York. A megachurch is an evangelical Christian assembly with more than 2000 attendees, who meet in a large arena for teaching and worship (Thumma, 2008; Goh, 2008). Modern megachurches have a significant role in re-building interest and engagement with the Christian religion. Many megachurches are classed as being a "digital ministry" where online video and chat enhance the interaction between the preacher and the congregation. Megachurches are branded, and since many of the churches are global, they need to manage a global brand, and hence must attend to their digital presence, reputation and identity (Thumma, 2008). Such churches have succeeded in attracting young, professional and highly educated individuals who are typically 'digital natives', for whom use of the internet and engagement with others of a like mind through social media is integral to their way of life.

The structure of Hillsong is pyramidal with lead pastors, controlled and supervised by a senior pastor. Local congregations have teams which perform various roles in the ministry. At the centre of the local structure is a senior pastor, with overall responsibility for the strategy, direction and operations, including logistics, information technology, production, performing arts and worship teams. Community groups, with a range of different roles and activities, constitute the fundamental infrastructure of the church and its congregation. For example, the Kids and Families community groups comprises parents and children; they arrange meals for 
families, and offer transportation assistance. Powerhouse and Velocity (community groups within the church) lead the church in the areas of film, TV and media and performing arts. Churches also run local community services, which includes counselling services, prison support services, and outreach teams for social engagement.

The Church of England (CofE) is a member of the Anglican Communion, a family that consists of millions of Christians who are members of 45 different churches. The roots of the Church of England go back to the time of the Roman Empire, when a Christian church came into existence in what was then the Roman province of Britain. The 'modern' Church of England emerged in the reign of Elizabeth 1, and has since undergone a number of significant transitions. Today, 'the Church of England plays a vital role in the life of the nation, proclaiming the Christian gospel in words and actions and providing services of Christian worship' (www.churchofengland.org/more/media-centre/chunch-england-glance).

The Church has an important role in building communities and providing services of Christian worship within various urban, rural and suburban areas. The Church of England is divided into two provinces - Canterbury and York. There are 41 dioceses in England, each of which have a structure of boards and councils responsible for ministry, education, mission and social responsibility. The Archbishop's Council plays a key governance role. The church has 16,000 churches and 42 maintained cathedrals. The worshiping community of the CofE in 2015 was 1.1 million people. The church has around 80,000 volunteers and 2,700 staff. There are strong links between church and state, with the Monarch being the Supreme Governor of the Church; they are responsible for appointing the Archbishops, Bishops and the Deans of Cathedrals. The two Archbishops and 24 Senior Bishops sit in the House of Lords and hold key UK government positions.

The Church established a digital team of six people in 2016, all with website, and social media experience. The team has three key work areas: evangelism, discipleship, and campaigning, which they promote through: a growing social media presence, national websites, and other technologies (such as voice and apps). The team play a key role in equipping and enabling local churches to develop their digital presence (www.churchofengland.org/about/renewalreform/digital).

Both churches are faced with the challenges posed by consumerism, information technology and diverse cultures (Cray et al., 2010). The core aim of both of the churches is to impact on the lives of people through a mission focus that promotes discipleship towards the 
establishment of 'a living Christian faith' (Cray et al., 2010). More specifically, their missions are similar, but with subtle differences. The short mission statement of the Church of England, which is shown as part of their brand logo is 'A Christian presence in every community', and their core belief statement, as shown on the opening image on their web page is 'We believe and trust in one God, Father Son and Holy Spirit' (www.churchofengland.org). Their belief system is embedded in The Apostles Creed, a summary of Christian faith that has been handed down over the centuries, and remains central to 'rites of passage' such as baptism. Hillsong's mission is also on their web page: 'Hillsong is a church that believes in Jesus, a church that loves God and people' and 'Overwhelmed by the gift of salvation we have found in Jesus we have a heart for authentic worship and are passionate about the local church and are on a mission to see God's kingdom established across the earth'.

\subsection{Procedures}

\subsubsection{Content analysis approach}

In order to explore how the two churches used social media, a content analysis of their respective social media presences was conducted. This research adopts a broad qualitative approach to content analysis that aligns with Holsti (1969, p.14)'s definition: 'Content analysis is any technique for making inferences by objectively and systematically identifying specified characteristic of messages'. Indeed, this research does not delve in-depth into the characteristics of messages, nor as would be expected of a quantitative analysis, does it undertake counting of messages; rather it focusses on making judgements on the purpose of messages in a way that indicates the uses of social media by various church leaders, officials and members.

The first stage of the research involved profiling the extent and nature of the social media presence of each of the two churches. This involved identifying the social media platforms that the two churches were using and then examining the instantiations of those presences for the people who were involved in posting messages of those platforms. Social media presences were identified through the websites of Hillsong and the Church of England. Stage 1 generated insights in its own right, but was also preparatory to Stage 2, in that it established the dataset of social media presences to be examined in Stage 2. Stage 1 revealed that Hillsong and its community groups uses four platforms: Facebook, Twitter, Instagram, and YouTube. The 
Church of England uses seven platforms: Facebook, Twitter, Instagram, YouTube, Sound Cloud, Pinterest, and Tumblr. In order to facilitate comparison between the social media presences of the two churches, data collection for Stage 2 focused on Facebook, Twitter, Instagram, and YouTube.

Stage 2 focussed on the development of a social media uses typology. The goal of a typology is to classify diverse behaviour into meaningful categories (Barnes et al., 2007). The classification developed was informed by previous typologies of social media use in non-profit organisations (e.g. Lovejoy and Saxton, 2012; Auger, 2013; DePaula et al., 2018). A qualitative content analysis approach (Lai \& To, 2015; Mayring, 2014) was taken to the analysis of the of the social media posts. Since the purpose of the analysis was not to undertake an in-depth interpretation of the content of individual posts, nor to profile the numbers of posts in each category, but rather to identify social media uses (or types of posts), the approach adopted involved an iterative identification types of posts.

The development of the typology was an iterative inductive process involving four steps:

1. Analysis of Hillsong's social media presences. By analysing the posted comments and messages, the uses of Hillsong's social media presences on Facebook, Twitter, Instagram and You-Tube were identified. Hillsong had a number of accounts for most of these platforms, including those used mainly by the leaders of the church and those used by church groups and their members (e.g. Kids). All live accounts were inspected. Comments on these accounts posted during the data collection period were analysed for their purpose or use.

2. Proposal of the first iteration of the Social Media Uses Typology. On the basis of the social media uses associated with Hillsong, a number of different types of use were identified, which, by the end of the data collection process, formed the basis for a preliminary proposal of a set of theoretical categories of use (Eto and Kynhas, 2008). Next, sites were re-visited in order to optimise the reliability and validity of the categories, to check for any other emergent categories and to extract examples of each of the categories. This process was informed by ongoing discussion between the two researchers.

3. Analysis of the Church of England's social media presences. By analysing the posted comments and messages, the uses of the Church of England's social media presences on Facebook, Twitter, Instagram and You-Tube were identified. The CofE had a number of accounts for most of these platforms, including those used mainly by the leaders of the church (e.g.Archbishop Justin Welby and Archbishop John Sentamu) and those used by church groups 
and their members. All live accounts were inspected. Comments on these accounts posted during the data collection period were analysed for their purpose or use. In coding uses, where appropriate the codes developed in Step 2, based on the Hillsong analysis, were used, but the researchers were also alert to the potential for different uses to emerge.

4. Confirmation of the Social Media Uses Typology. The first iteration of the typology was reconsidered and found to cover most of the uses encountered in both the Hillsong and CofE social media presences. However, additional uses were also identified, coded, and added to complete the typology.

\section{Findings}

\subsection{Social Media Landscape for Churches}

Table 1 shows the categories in the typology, together with their sub-categories. These categories and sub-categories are defined and discussed further in section 4.2. This section focusses on the extent of use of different platforms for different purposes as summarised in Table 1. The 'Church' column in Table 1 indicates whether the each of the churches engages in each of the specific uses of social media; it summarises the other columns in the table. It is evident, that both churches use social media in 'building a brand', and that both of them use all four social media platforms for both 'information provision' and 'promotion'. They also both use Facebook and Twitter for 'cross promotion'. They also both use social media for 'recognition', to congratulate church community members. (one aspect of building the church's community). Again, this is done through both Facebook and Twitter, by both churches. Finally, on areas of similarity, they both use social media, and in this instance, all four platforms, to seek to promote 'spiritual wellness' through bible quotes and messages, a function that aligns with their core mission. On the other hand, there is a very marked difference between the two churches, in respect of the use of social media for outreach. Hillsong does this through Facebook, Twitter, and to some extent Instagram, but there is no evidence of the Cof E using social media for 'outreach'.

In terms of the use of the different social media platforms, Twitter and Facebook have the widest range of different types of use by both Hillsong and CofE, and for each church, the uses that have been identified on Facebook, match those identified on Twitter. On the other hand, 
the nature of these uses varies slightly between the churches, with the CofE not using either platform for 'events', and, Hillsong not using either Facebook or Twitter for 'reconciliation'.

More generally, these two churches have begun to appreciate and experiment with the use of social media to communicate and share content with existing members, and to strengthen links between the members of the church community. Youtube is particularly useful for promoting the church, and providing church members with access to videos and live streaming services. Both Hillsong and the CofE use social media for branding and promotion. Hillsong, with its large diverse and scattered communities, is particularly proactive in using social media to sell conference tickets, support sharing of music videos, and sharing images of recent events, all of which communicate a sense of a lively and interesting community.

In addition to the general social media presence of the churches, both churches have a number of local or special interest groups that also have a social media presence. The format and role of these varies considerably. For example, in Hillsong, three communities, family, wildlife and sisterhood are using Facebook for community building and the promotion of events. Similarly, the CofE has several community pages based on dioceses and parishes that are using Facebook.

Insert Table 1 here

\subsection{Proposing a Social Media Use Typology for Churches}

Table 2 identifies the main categories and sub-categories of social media use in churches. Four main categories are proposed: building a brand, building the church community, outreach, and, spiritual mission; for each of these categories it is possible to identify a number of subcategories (Table 2). Together, these categories and sub-categories comprise the Social Media Use Typology for Churches. As discussed later, there is some alignment between this typology and those previously identified in other contexts. In addition, this typology represents a generalisation; there are differences between the uses of social media between two churches, and in relation to their use of specific social media platforms.

Table 2 also offers definitions of each of the sub-categories; these are distilled from extensive exploration of the posts on the four social media platforms associated with the two churches. Where available, these definitions are accompanied by examples of posts. 


\section{Discussion and Conclusion}

Whilst previous research associates megachurches, such as Hillsong, with a digital ministry (Kim, 2007; Eagle, 2015), research into the church's use of the Internet is limited and there have been no previous studies on their use of social media. Through an extensive analysis of the social media posts of Hillsong and the Church of England, this study offers some insights into the uses, and potential benefits, of social media to churches and their communities. Both churches have an array of different social media presences, typically intended for different church community groups and uses. Amongst other social media researchers, only Auger (2013) has explored the use of more than one social media platform in non-profit organizations. In line with Kietzmann et al. (2011), who point to the different functionalities of the different sites, Auger (2013) suggested that organizations were using different social media platforms for different purposes. There is no clear evidence of such discrimination in the churches in this study. In addition, many of the prior studies (e.g. Gillooly, et al., 2017; Guo and Saxton, 2014; Lovejoy and Saxton, 2012) focus solely on Twitter. Further comparative studies of the uses of different social media platforms, possibly leading to a series of social media platform specific typologies of uses, would support the development of more targeted social media strategies.

The social media uses typology proposed in this article also has a degree of alignment with other typologies generated for other non-profit organizations. The earlier social media use typologies for non-profit organizations proposed by Auger (2013), Guo and Saxton (2014) and Lovejoy and Saxton (2012), and share the same three main social media use categories: Information, Community, Action. They tend not to develop sub-categories of Information, but offer a range of sub-categories for Community, including for example, giving thanks and recognition, and acknowledgement of current and local events. There is considerable overlap between the Community sub-categories in this article, and the Community sub-categories in Auger (2013) and Lovejoy and Saxton (2012). There is also some alignment between the 'Building a brand' category in this article and the Information category in previous typologies (Auger, 2013; Lovejoy and Saxton, 2012). However, there are two categories that are unique to this study and that are particularly salient for churches, viz, outreach and developing spiritual mission. The uniqueness of these two categories points to the need for further investigation into the impact of context on the use of social media by non-profit organizations. 


\section{Suggestions for further research and practice}

The overriding sense is that the social media presences of Hillsong and the Church of England are complex, being scattered across platforms, and having several groups on some platforms. It would appear that social media page 'owners' such as church leaders and local churches, are using their Facebook pages and other social media presences to communicate, and that each is doing this in a way that is consistent with their personality and role. In other words, if Hillsong and the $\mathrm{C}$ of $\mathrm{E}$ have a social media strategy it is distributed and emergent, rather than directed and specified. Whilst this approach may align with the culture of these two churches, the church leaders would benefit from reflecting on the social media strategies for their churches, formulating objectives (possibly for different groups within the churches) and considering mechanisms for evaluating and enhancing the effectiveness of their social media presence.

Despite the useful insights that this research has generated, it does have a number of limitations, some of which represent opportunities for further research, both in churches, and in the nonprofit sector, and more widely. More specifically the main limitations are: the focus on only two churches, both of which are in the UK; the focus on 'uses' of social media, as opposed to style of engagement, or the impact of social media communication; the absence of a critical evaluation of the missions of the two churches; the use of a qualitative content analysis approach; and, the spread across four social media platforms. To address these limitations, and to undertake a wider exploration of the use, role and impact of social media on churches and other non-profit organizations, we offer a number of suggestions for future research:

- Further in-depth analysis of why churches and other non-profit organizations use social media and the extent to which they have shared objectives and strategies regarding social media use, as a basis for the development of stronger theoretical models.

- An exploration of the use of social media by the Church of England and Hillsong in different countries in the world (e.g. United States, Australia, Africa, and countries in which church members are constrained from meeting openly)

- Further comparative studies of social media strategies and use in churches of different denominations, including 'non-Christian' churches, offering the opportunity to explore the relationship between mission and social media strategies and communication styles. 
- Evaluation of the use of social media in churches, including not only the broader impact on church communities and the evolution and communication of the spiritual message, but also their engagement in the use of social media analytics.

- A survey of church members regarding the value and importance of social media in promoting their relationship with their church.

- More detailed comparative studies of the use and uses of social media by church leaders, and by church groups with specific remits.

- Developing understanding of how churches share practice and learn to hone and target their social media activities.

- The availability, nature, and evaluation of training and development in social media communication for church leaders.

\section{References}

Auger, G.A. (2013). Fostering democracy through social media: evaluating diametrically opposed nonprofit advocacy organizations' use of Facebook, Twitter, and YouTube. Public Relations Review, 39, 369-376. doi:10.1016/j.pubrev.2013.07.013

Bacile, T., Ye, C. \& Swilley, E. (2014). From firm-controlled to consumer-contributed: consumer co- production of personal media marketing communication. Journal of Interactive Marketing, 28, 117-133. doi:10.1016/j.intmar.2013.12.001

Barnes, S.J., Bauer, H.H., Neumann, M.M. \& Huber, F. (2007). Segmenting cyberspace: a customer typology for the internet. European Journal of Marketing, 4, 71-93.

doi:10.1108/03090560710718120

Bortree, D.S. \& Seltzer, T. (2009). Dialogic strategies and outcomes: An analysis of environmental advocacy groups' Facebook profiles. Public Relations Review, 35, 317-319. Doi:10.1016/j.pubrev.2009.05.002

Bryman, A. \& Bell, E. (2011). Business Research Methods (3rd ed.). Oxford University Press, Oxford.

Campbell, H. A. (2012). Understanding the relationship between religion online and offline in a networked society. Journal of the American Academy of Religion, 80, 64-93. 
Chen, Y., Fay, S. \& Wang, Q. (2011). The role of marketing in social media: how online consumer reviews evolve. Journal of Interactive Marketing, 25, 85-94.

doi:10.1016/j.intmar.2011.01.003

Cheong, P.H. (2014). Tweet the message? Religious authority and social media innovation. Journal of Religion, Media \& Digital Culture, 3(3), 1-19.

Cheong, P.H. (2017). The vitality of new media and religion: Communicative perspectives, practices, and changing authority in spiritual organization. New Media \& Society, 19: 25-33. Connell, J. (2005). Hillsong: A megachurch in the Sydney suburbs. Australian Geographer, 36, 315-332. Doi:10.1080/00049180500325710

Cray, G., Mobsby, I.\& Kennedy, A. eds. (2010). New Monasticism as Fresh Expressions of Church. Canterbury Press, Norwich

Eagle, D.E. (2015). Historicizing the megachurch. Journal of Social History, 48, 589-604. doi:10.1093/jsh/shu109

Eisenhardt, K.M. (1989). Building theories from case study research. Academy of Management Review, 14, 532-550. doi:10.4135/9781473915480.n52

Ellison, N. \& Hardey, M. (2014). Social media and local government: citizenship, consumption and demoncracy. Local Government Studies, 40, 21-40.

doi:10.1080/03003930.2013.799066

Farquhar, L \& Davidson, T. (2019). From Facebook to Instagram: the role of social media in religious communities. In: Religion Online: How Digital Technology is Changing the Way we Worship/edited by A E Grant, D. A. Stout, C.H. Chen \& A.F.C. Sturgill. ABC-CLIO. Pp. $27-$ 46.

Goh, R.B.H. (2008). Hillsong and 'megachurch' practice: semiotics, spatial logic and the embodiment of contemporary evangelical Protestantism. Material Religion: The Journal of Objects, Art and Belief, 4, 284-304. doi: 10.2752/175183408X376665

Gummerus, J., Liljander, V., Weman,E. \& Pihlström.M. (2012). Customer engagement in a Facebook brand community. Management Research Review, 35, 857-877. doi: $10.1108 / 01409171211256578$ 
Guo, C. \& Saxton, G.D. (2014). Tweeting social change: how social media are changing nonprofit advocacy. Nonprofit and Voluntary Sector Quarterly, 43, 57-79. doi: 10.1177/0899764012471585

Gupta, A., Tyagi, M. \& Sharma, D. (2013). Use of social media marketing in healthcare. Journal of Health Management, 15, 293-302. doi: 10.1177/0972063413489058

Hackett, R.I.J. (2009). The new virtual (inter)face of African Pentecostalism. Society, 46, 496-503. doi: 10.1007/s12115-009-9254-1

Holsti, O.R. (1969). Content analysis for the social sciences and humanities. AddisonWesley, Reading, MA.

Hutchings, T. Contemporary religious community and the online church. Information, Communication \& Society, 14, 1118-1135.

Kietzmann, J., Hermkens, K, McCarthy, I.P. \& Silvestre, B.S. (2011). Social media? Get serious! Understanding the functional building blocks of social media. Business Horizons, 54, 241-251.

Kim, K. (2007). Ethereal Christianity: reading Korean mega-church websites. Studies in World Christianity, 13, 208-224. doi:10.3366/swc.2007.13.3.208

Kim. A.J. \& Ko, E. (2012). Do social media marketing activities enhance customer equity? An empirical study of luxury fashion brands. Journal of Business Research, 65, 1480-1486. doi:10.1016/j.jbusres.2011.10.014

Klaver, M. (2015). Media technology creating 'sermonic events.' the Hillsong megachurch network. CrossCurrents, 65, 422-433. doi:10.1111/cros.12164

Kreander, N., McPhail, K. \& Molyneaux, D. (2004). God's fund managers: A critical study of stock market investment practices of the Church of England and UK Methodists. Accounting, Auditing \& Accountability Journal, 17, 408-441. doi:10.1108/09513570410545803

Lai, L.S.L., \& To, W.M. (2015). Content analysis of social media: a grounded theory approach. Journal of electronic Commerce Research, 16, 138-152.

Laughlin, R.C. (1988). Accounting in its social context: An analysis of the accounting systems of the Church of England. Accounting, Auditing \& Accountability Journal, 1, 19-42. doi:10.1108/EUM0000000004622 
Lee. M. \& Youn, S. (2009). Electronic word of mouth (eWOM): how eWOM platforms influence consumer product judgement. International Journal of Advertising, 28, 473-478. doi:10.2501/S0265048709200709

Levitt, M. (2003). Where are the men and boys? The gender imbalance in the Church of England. Journal of Contemporary Religion, 18, 61-75. doi:10.1080/13537900305488 Lovejoy, K., Waters, R.D. \& Saxton, G.D. (2012). Engaging stakeholders through Twitter: how nonprofit organisations are getting more out of 140 characters or less. Public Relations Review, 38, 313-318. doi:10.1016/j.pubrev.2012.01.005

Lovejoy. K. \& Saxton, G.D. (2012). Information, community, and action: how nonprofit organizations use social media. Journal of Computer-Mediated Communication, 17, 337353. doi:10.1111/j.1083-6101.2012.01576.x

Martin, P.P., Bowles, T.A., Adkins, L. \& Leach, M.T. (2011). Black mega-churches in the internet age: exploring theological teachings and social outreach efforts. Journal of African American Studies, 15, 55-176. doi: 10.1007/s12111-011-9181-2

Mayring, O. Qualitative content analysis: theoretical foundation, basic procedures and software solution. Gesis, Leibniz.. https://nbn-resolving.org/urn:nbn:de:0168-ssoar-395173 McIntyre, E.H. (2007). Brand of Choice: Why Hillsong music is winning sales and souls. Australian Religion Studies Review, 20, 175-194. doi:10.1558/arsr.v20i2.175

Muskett, J.A. (2015). Reflections on the shop windows of the Church of England: Anglican Cathedrals and vicarious religion. Journal of Contemporary Religion, 30, 273-289. doi:10.1080/13537903.2015.1025557

Nah, S. \& Saxton, G.D. (2013). Modelling the adoption and use of social media by non-profit organisations. New Media and Society, 15, 294-313. doi: 10.1177/1461444812452411

Okazaki, S., Díaz-Martín, A.M., Rozano, M. \& Menéndez-Benito, M.D. (2015). Using Twitter to engage with customers: a data mining approach. Internet Research, 25, 416-434. doi:10.1108/IntR-11-2013-0249

Rupp, W.T. \& Smith, A.D. (2002). A Study of interrelationships between the Internet and religious organisations: an application of diffusion theory. Services Marketing Quarterly, 24(2), 29-41. 
Rowley, J. (2002). Using case studies in research. Management Research News. 25, 16- 27. doi:10.1108/01409170210782990

Rybalko, S. \& Seltzer, T. (2010). Dialogic communication in 140 characters or less: how Fortune 500 companies engage stakeholders using Twitter. Public Relations Review, 36, 336341. doi:10.1016/j.pubrev.2010.08.004

Sani, F. \& Reicher, S. (2000). Contested identities and schisms in groups: opposing the ordination of women as priests in the Church of England. British Journal of Social Psychology, 39, 95-112. doi:10.1348/014466600164354

Saxton, G.D. \& Waters, R.D. (2014). What do stakeholders like on Facebook? Examining public reactions to nonprofit organizations' informational, promotional, and communitybuilding messages. Journal of Public Relations Research, 26, 280-299. doi:10.1080/1062726X.2014.908721

Schlagwein, D. \& Hu, M. (2017). How and why organisations use social media: five use types and their relation to absorptive capacity. Journal of Information Technology, 32, 194209. doi:10.1057/s41265-018-0057-y

Sturgill, A. (2004). Scope and purposes of church web sites. Journal of Media \& Religion, 3, 165-176. doi:10.1207/s15328415jmr0303_3

Thumma, S. \& Bird,W. (2008). Changes in American megachurches: tracing eight years of growth and innovation in the nation's largest-attendance congregations. ScholarWorks. Retrieved from: http://hdl.handle.net/1805/5657 Trainor, K.J., Andzulis, J.M., Rapp, A. \& Agnihotri, R. (2014). Social media technology usage and customer relationship performance: a capabilities-based examination of social CRM. Journal of Business Research, 67, 1201-1208. doi:10.1016/j.jbusres.2013.05.002 Wade, M. (2015). Seeker-friendly: The Hillsong megachurch as an enchanting total institution. Journal of Sociology, 52, 661-67. doi:10.1177/1440783315575171

Wang, R., Yang, F. \& Haigh, M.M. (2017). Let me take a selfie: exploring the psychological effects of posting and viewing selfies and groupies on social media. Telematics and Informatics, 34, 274-283. doi:10.1016/j.tele.2016.07.004 
Waters, R.D. \& Jamal, J.Y. (2011). Tweet, tweet, tweet: A content analysis of nonprofit organizations' Twitter updates. Public Relations Review, 37, 321-324.

doi:10.1016/j.pubrev.2011.03.002

Zigan, K. \& Le Grys, A. (2018). Towards an understanding of social responsibility within the Church of England. Journal of Business Ethics, 149, 535-560. doi:10.1007/s10551-016$3104-Z$ 


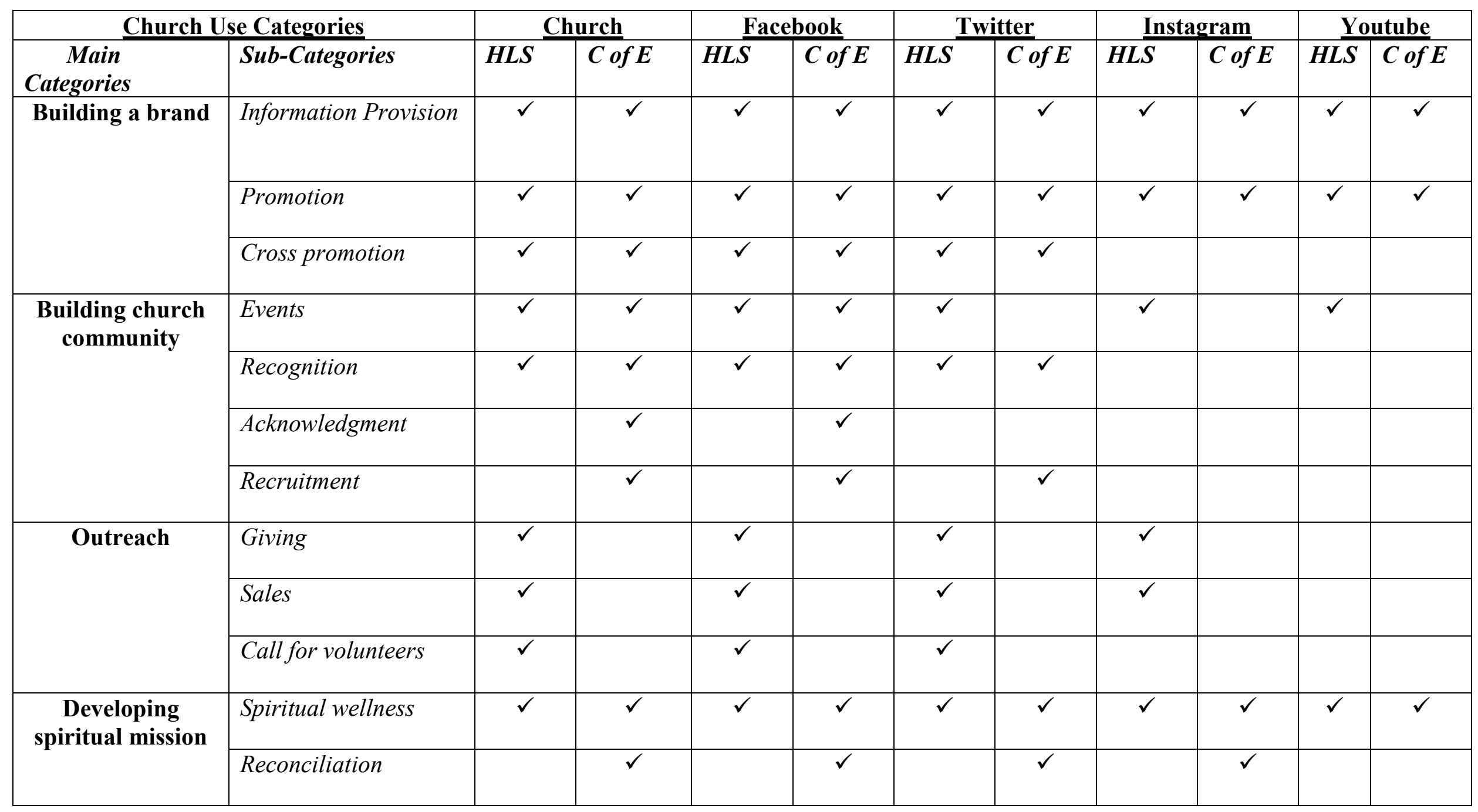

Table 1: Social media platforms and their uses. 


\begin{tabular}{|c|c|c|c|c|}
\hline $\begin{array}{c}\text { Main } \\
\text { Category }\end{array}$ & Sub -categories & Definition & Example post by $\mathrm{C}$ of $\mathrm{E}$ & Example post by HLS \\
\hline \multirow[t]{3}{*}{$\begin{array}{l}\text { Building a } \\
\text { brand }\end{array}$} & $\begin{array}{l}\text { Information } \\
\text { provision }\end{array}$ & $\begin{array}{l}\text { Information about the church, its } \\
\text { services and events, and its } \\
\text { community. }\end{array}$ & $\begin{array}{l}\text { Looking to attend a church service tomorrow? Visit } \\
\text { www.achurchnearyou.com to find one local to you }\end{array}$ & $\begin{array}{l}\text { Tomorrow is Sunday! We can't wait to } \\
\text { welcome you in church! Who will you bring } \\
\text { along? }\end{array}$ \\
\hline & Promotion & $\begin{array}{l}\text { Announcing and marketing church } \\
\text { activities and opportunities }\end{array}$ & $\begin{array}{l}\text { Are you following the Church of England on Instagram yet? } \\
\text { Find us here: https://www.instagram.com/thechurchofengland/ }\end{array}$ & $\begin{array}{l}\text { We're excited to announce that } \\
\text { @HillsongYoungAndFree have a new live } \\
\text { album coming out this Friday! All the songs } \\
\text { from their studio album III recorded live at } \\
\text { \#HillsongConf this year! Can't wait for you } \\
\text { to hear it! }\end{array}$ \\
\hline & Cross Promotion & $\begin{array}{l}\text { Promoting different faith, } \\
\text { denominations or non-profit } \\
\text { organisation's activities or other } \\
\text { calls to action. }\end{array}$ & $\begin{array}{l}\text { Thanks to Archbishop XXX, Archbishop of London for the } \\
\text { Coptic Orthodox Church, for tweeting these great photos of his } \\
\text { meeting with Bishop of London, XXX XXX. They discussed } \\
\text { ministry objectives and ways to continue and expand on years } \\
\text { of collaboration in \#London }\end{array}$ & $\begin{array}{l}\text { @realjohngray is speaking TONIGHT at } \\
\text { Hillsong Conference! Invite friends and join } \\
\text { us for the closing night of \#HillsongConf! } \\
\text { Only few seats left, don't miss out! Register }\end{array}$ \\
\hline \multirow[t]{3}{*}{$\begin{array}{l}\text { Building } \\
\text { church } \\
\text { community }\end{array}$} & Events & $\begin{array}{l}\text { Encouraging members to join } \\
\text { others and share in church events }\end{array}$ & $\begin{array}{l}\text { Join us on Facebook LIVE on Wednesday, } 23 \text { May } 2018 \text { at } \\
7.30 \mathrm{pm} \text { to be among the first to hear about an exciting digital } \\
\text { project we're launching, which aims to enable millions to grow } \\
\text { their faith and help those exploring Christianity to find out } \\
\text { more. Watch along and let us know you've tuned in by sending } \\
\text { us a comment. See you on Wednesday! }\end{array}$ & $\begin{array}{l}\text { Girls, register now for \#ColourConf } 2019 \\
\text { and make the most out of our last price } \\
\text { break. Save } £ 20 \text { by registering before } \\
\text { midnight. }\end{array}$ \\
\hline & Recognition & $\begin{array}{l}\text { Messages to congratulate } \\
\text { members of the church community }\end{array}$ & $\begin{array}{l}\text { Thanks to Rev XXX for sharing this on Twitter today: "When } \\
\text { I was a little boy I learned to pray with my heart. I learned that } \\
\text { in praying. Let your soul pray. Let it shout. Help is only a prayer } \\
\text { away" }\end{array}$ & $\begin{array}{l}\text { We're grateful for every volunteer who helped } \\
\text { \#HillsongCarols happen! Thank you! }\end{array}$ \\
\hline & Acknowledgment & $\begin{array}{l}\text { Messages to thank community } \\
\text { members for their contribution }\end{array}$ & $\begin{array}{l}\text { Hi Mary, thanks for your comment. Are you having problems } \\
\text { with the link in this post? }\end{array}$ & \\
\hline
\end{tabular}




\begin{tabular}{|c|c|c|c|c|}
\hline & Recruitment & $\begin{array}{l}\text { Informing community members of } \\
\text { employment opportunities and } \\
\text { inviting them to apply. }\end{array}$ & $\begin{array}{l}\text { Do you have experience managing digital agencies and large } \\
\text { website projects? If so, we're recruiting a new web manager role } \\
\text { to oversee the Church of England and Archbishops' websites: } \\
\text { http://bit.ly/2IB2orU } \\
\text { \#digital \#web \#websites }\end{array}$ & \\
\hline \multirow[t]{3}{*}{ Outreach } & Giving & $\begin{array}{l}\text { Encouraging community members } \\
\text { to give money to the church, } \\
\text { charities and to people in need. }\end{array}$ & & 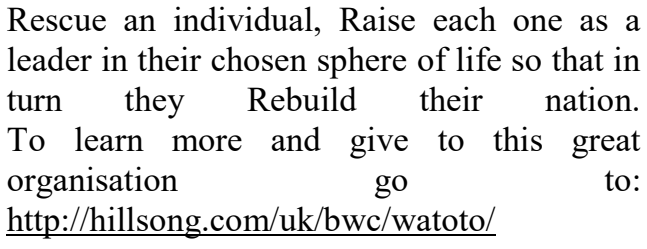 \\
\hline & Sales & $\begin{array}{l}\text { Messages to sell tickets or bible } \\
\text { resources }\end{array}$ & & $\begin{array}{l}\text { CAROLS....IS....COMING! Get your } £ 5 \\
\text { tickets at } \underline{\text { Hil.so/Carols }} \text { or at the Hillsong App }\end{array}$ \\
\hline & Call for volunteers & $\begin{array}{l}\text { Requests to the community } \\
\text { members to work for a cause } \\
\text { and/or to help the church. }\end{array}$ & $\begin{array}{l}\text { What if the Church saw blood and organ donation as part of its } \\
\text { giving? Find more information and resources at } \\
\text { www.fleshandblood.org }\end{array}$ & $\begin{array}{l}\text { Sit Together. Serve Together. \#HillsongConf } \\
\text { wouldn't be the same without our incredible } \\
\text { volunteers! If you want to get involved, } \\
\text { volunteer registrations close at midnight! Tap } \\
\text { on the link in the bio and make sure to use } \\
\text { TEAM2018 code. } \\
\text { Hillsong.co.uk/volunteer }\end{array}$ \\
\hline \multirow[t]{2}{*}{$\begin{array}{l}\text { Developing } \\
\text { spiritual } \\
\text { mission }\end{array}$} & Spiritual Wellness & $\begin{array}{l}\text { Bible quotes and messages } \\
\text { designed to engage church } \\
\text { members in spiritual practice and } \\
\text { experience. }\end{array}$ & $\begin{array}{l}\text { Here is today's prayer from the Church of England: God of } \\
\text { constant mercy, who sent your Son to save us: remind us of your } \\
\text { goodness, increase your grace within } \\
\text { that our thankfulness } \\
\text { through may }\end{array}$ & $\begin{array}{l}\text { Therefore, if anyone is in Christ, he is a new } \\
\text { creation; old things have passed away; behold, } \\
\text { all things have become new." } 2 \text { Corinthians } \\
\text { 5:17 (NKJV) }\end{array}$ \\
\hline & Reconciliation & $\begin{array}{l}\text { Messages and statements deigned } \\
\text { to encourage community members } \\
\text { to accept, live with and love one } \\
\text { another through disagreements }\end{array}$ & $\begin{array}{l}\text { A prayer for reconciliation after the EU Referendum } \\
\text { http://bit.ly/28UAJoJA \#Prayer for \#reconciliation after the } \\
\text { \#EU \#Referendum }\end{array}$ & \\
\hline
\end{tabular}

Table 2: Definitions and examples of categories of church social media use 